Review

\title{
Insight into the Molecular and Functional Diversity of Cnidarian Neuropeptides
}

\author{
Toshio Takahashi ${ }^{1, *}$ and Noriyo Takeda ${ }^{2}$ \\ 1 Suntory Foundation for Life Sciences, Bioorganic Research Institute, Osaka 618-8503, Japan \\ 2 Research Center for Marine Biology, Asamushi, Graduate School of Life Sciences, \\ Tohoku University, Aomori 039-3501, Japan; E-Mail: ntakeda@m.tohoku.ac.jp \\ * Author to whom correspondence should be addressed; E-Mail: takahashi@sunbor.or.jp; \\ Tel.: +81-75-962-6105; Fax: +81-75-962-2115.
}

Academic Editor: Brijesh Tiwari

Received: 22 December 2014 / Accepted: 15 January 2015 / Published: 23 January 2015

\begin{abstract}
Cnidarians are the most primitive animals to possess a nervous system. This phylum is composed of the classes Scyphozoa (jellyfish), Cubozoa (box jellyfish), and Hydrozoa (e.g., Hydra, Hydractinia), which make up the subphylum Medusozoa, as well as the class Anthozoa (sea anemones and corals). Neuropeptides have an early evolutionary origin and are already abundant in cnidarians. For example, from the cnidarian Hydra, a key model system for studying the peptides involved in developmental and physiological processes, we identified a wide variety of novel neuropeptides from Hydra magnipapillata (the Hydra Peptide Project). Most of these peptides act directly on muscle cells and induce contraction and relaxation. Some peptides are involved in cell differentiation and morphogenesis. In this review, we describe FMRFamide-like peptides (FLPs), GLWamide-family peptides, and the neuropeptide Hym-355; FPQSFLPRGamide. Several hundred FLPs have been isolated from invertebrate animals such as cnidarians. GLWamide-family peptides function as signaling molecules in muscle contraction, metamorphosis, and settlement in cnidarians. Hym-355; FPQSFLPRGamide enhances neuronal differentiation in Hydra. Recently, GLWamide-family peptides and Hym-355; FPQSFLPRGamide were shown to trigger oocyte maturation and subsequent spawning in the hydrozoan jellyfish Cytaeis uchidae. These findings suggest the importance of these neuropeptides in both developmental and physiological processes.
\end{abstract}


Keywords: cnidaria; hydra; jellyfish; coral; neuropeptide

\section{Introduction}

Neurotransmission is the process by which signaling molecules called neurotransmitters, including peptides, are released by a neuron and bind to and activate the receptors of another neuron. Neuropeptides include small peptides and peptide hormones derived from nerve cells and range from as short as three amino acids (e.g., thyrotropin-releasing hormone) [1] to as long as 70 or more (e.g., eclosion hormone) [2]. Neuropeptide receptors are primarily members of the large family of $\mathrm{G}$ protein-coupled receptors (GPCRs), although notable exceptions are found. Some neuropeptides directly gate ion channels [3], whereas insulin, which is a neuropeptide in some invertebrates [4], signals through its traditional tyrosine kinase insulin receptor. Finally, neurons secrete a multitude of other proteinaceous factors (e.g., growth factors) that signal through diverse receptor types. We will restrict this review to a discussion of three types of neuropeptides found in cnidarians. Readers interested in GPCRs may refer to a recent excellent review in cnidarians [5].

Cnidarians have a diffuse nervous system including a nerve net in which the sensory and ganglionic neurons and their processes are interspersed among the epithelial cells of both layers. Cnidarian nervous systems are strongly peptidergic, not solely peptidergic [6]. Classical neurotransmitters such as the biogenic amines that have long been studied as major neurotransmitters in higher eukaryotes are also involved in cnidarian neurotransmission [7]. The prevailing view of the nervous system in the freshwater polyp Hydra (Hydrozoa) is that the neuronal network is simple and diffuse throughout the animal's body. As to the hydrozoan medusae, marginal nerve rings and ganglion-like structures associated with sensory organs are observed. Using the model organism Hydra, which can be used to study not only cell biological and regenerative mechanisms but also physiological processes regulated by peptide signaling molecules, we developed a novel peptidomic approach to the isolation and identification of functional peptide signaling molecules for this organism (the Hydra Peptide Project) [8]. Over the course of this project, we identified a variety of neuropeptides. Most of these peptides are novel, but some peptides are homologous to peptide families that have previously been identified.

For example, GLWamide-family peptides (GLWamides), which were first isolated from the sea anemone Anthopleura elegantissima [9] and then from Hydra magnipapillata [8], induce the metamorphosis of Hydractinia serrata planula larvae into polyps. In Hydra, the peptides induce detachment of the bud from a parental polyp [8]. The neuropeptide Hym-355; FPQSFLPRGamide enhances neuronal differentiation by inducing multipotent interstitial stem cells to enter the neuronal differentiation pathway [10]. Grimmelikhuijzen and colleagues isolated four FMRFamide-like peptides (FLPs) from Hydra using a radioimmunoassay method [11]. We also identified the same peptides using high-throughput reverse-phase nano-flow matrix-assisted laser desorption/ionization mass spectrometry (LC-MALDI-MS/MS) [12]. LC-MALDI-MS/MS is a powerful tool that has been widely used in the study of biological systems $[13,14]$. Accumulating evidence suggests that Hydra peptides exist and function beyond cnidarian species. 
In this review, we describe FLPs, GLWamide-family peptides, and Hym-355; FPQSFLPRGamide, which have diverse functions as neuropeptides in cnidarians, including two species of Hydrozoa (Hydra, Hydractinia, and jellyfish) and Anthozoa (coral). We also discuss the importance of the neuropeptides in the development and physiology of the cnidarians.

\section{Cnidarian Neuropeptides}

\subsection{FLPs (FMRFamide-Like Peptides)}

The peptide FMRFamide, which is composed of four amino acid residues with $C$-terminal amidation, was first isolated from the cerebral ganglion of the clam Macrocallista nimbosa $[15,16]$. To date, peptides sharing a similar sequence have been isolated from other mollusks and from members of most other phyla. These peptides are now divided into two groups according to the level of structural similarity compared with FMRFamide. One group is FMRFamide-related peptides (FaRPs), which contain $N$-terminal extensions of the $C$-terminal FMRFamide or FLRFamide core sequences [17]. The other group is FLPs, which include all peptides with the RFamide sequence only [18]. Thus, FLPs include FaRPs and all other RFamide peptides. An excellent review has examined FaRPs from invertebrate animals [19]. The main focus of this review will be on cnidarian FLPs.

The evolutionarily "ancient" nervous systems in cnidarians express a variety of FLPs (Table 1). Peptides with GRFamide at the $C$-terminus have been found in a scyphozoan [20], three hydrozoans [11,21-25], and an anthozoan [26], whereas peptides with TRFamide and/or RRFamide at the $C$-terminus have been sequenced from another anthozoan [27].

Table 1. FMRFamide-like peptides in Cnidaria.

\begin{tabular}{cccc}
\hline Name & Peptide Sequence & Species & Reference \\
\hline Antho-RFamide & pQGRFamide & Anthopleura elegantissima & {$[26]$} \\
\hline Cyanea-RFamide I & pQWLRGRFamide & & \\
Cyanea-RFamide II & $\begin{array}{c}\text { pQPLWSGRFamide } \\
\text { Cyanea-RFamide III }\end{array}$ & Cyanea Lamarckii & {$[20]$} \\
\hline Pol-RFamide I & pQLLGGRFamide & \multirow{2}{*}{ Polyorchis penicillatus } & {$[21]$} \\
Pol-RFamide II & pQWLKGRFamide & & {$[22]$} \\
\hline Hydra-RFamide I & pQWLGGRFamide & & \\
Hydra-RFamide II & pQWFNGRFamide & Hydra magnipapillata & {$[11]$} \\
Hydra-RFamide III & KPHLRGRFamide & & \\
Hydra-RFamide IV & HLRGRFamide & & \\
\hline Hydra-RFamide V & pQLMSGRFamide & & \\
Hydra-RFamide VI & pQLMRGRFamide & & \\
Hydra-RFamide VII & pQLLRGRFamide & Hydra magnipapillata & {$[23]$} \\
Hydra-RFamide VIII & KPHYRGRFamide & & \\
Hydra-RFamide IX & HYRGRFamide & & \\
\hline Hydra-RFamide X & KPHLIGRFamide & \multirow{2}{*}{ Hydra magnipapillata } & {$[24]$} \\
Hydra-RFamide XI & pQLMTGRFamide & Hydractinia echinata & {$[25]$} \\
\hline He-RFamide & pQWLKGRFamide & Nematostella vectensis & {$[27]$} \\
\hline Nv-RFamide I & pQITRFamide & \multirow{2}{*}{ Nemide } &
\end{tabular}

pQ; pyroglutamate. Modified from [19]. 
All neuropeptides are produced and secreted by highly regulated secretion pathways. In general, the precursors of neuropeptides are incorporated into the endoplasmic reticulum as a preprohormone where they are converted into prohormones. They are then transported to the Golgi apparatus where they undergo post-translational modifications such as endoproteolysis and $C$-terminal amidation before assuming their final active peptide forms. Cnidarian FLP cDNAs have been identified from several different animals. A cDNA from Calliactis parasitica contains 19 copies of Antho-RFamide, two copies of FQGRFamide, and one of YVPGRYamide [28]. In A. elegantissima, two cDNAs have been isolated. One has 13 copies of Antho-RFamide (Table 1) and nine other FLPs, whereas the other has 14 copies of Antho-RFamide (Table 1) and eight other FLPs [29]. In Renilla kollikeri, 36 copies of Antho-RFamide (Table 1) are present [30]. A cDNA from Polyorchis penicillatus has one copy of Pol-RFamide I (Table 1) and 11 copies of Pol-RFamide II (Table 1) along with another predicted FLP [31]. The Hydra-RFamides are encoded by three different preprohormones. Preprohormone-A contains all four Hydra-RFamides (Table 1) [23]. Preprohormone-B contains one copy of Hydra-RFamide I (Table 1), one copy of Hydra-Hydra RFamide II (Table 1), and two putative Hydra-RFamides [23]. Preprohormone-C contains one copy of Hydra-RFamide I (Table 1) and seven copies of putative neuropeptide sequences [23]. Collectively, cnidarian FLP cDNAs encoding the precursors yield many neuropeptides and structural diversity, indicating functional diversity.

\subsection{GLWamides}

GLWamides have characteristic structural features in their $N$ - and $C$-terminal regions. For example, most of the peptides share a GLWamide motif at their $C$-termini (Table 2). In Hydra, seven GLWamide peptides $[8,32]$ were isolated and found to have a proline residue at the second position (X-Pro) or at the second and third positions (X-Pro-Pro) of their $N$-terminal regions (Table 2). Metamorphosin A (MMA), which was isolated from the anthozoan A. elegantissima [9], has a pyroglutamyl residue at the $N$-terminus (Table 2). Both of these $N$-terminal structures confer resistance to aminopeptidase digestion [33].

Table 2. GLWamide-family peptides in Cnidaria.

\begin{tabular}{cccc}
\hline Name & Peptide Sequence & Species & Reference \\
\hline MMA & pQQPGLWamide & Anthopleura elegantissima & {$[34]$} \\
\hline Hym-53 & NPYPGLWamide & & \\
Hym-54 & GPMTGLWamide & & \\
Hym-248 & EPLPIGLWamide & & \\
Hym-249 & KPIPGLWamide & Hydra magnipapillata & {$[8,32]$} \\
Hym-331 & GPPPGLWamide & & \\
Hym-338 & GPP'PGLWamide & & \\
Hym-370 & KPNAYKGKLPIGLWamide & & \\
\hline He-LWamide I & pQRPPGLWamide & \multirow{2}{*}{ Hydractinia echinata } & {$[35]$} \\
He-LWamide II & KPPGLWamide & & \\
\hline
\end{tabular}


Table 2. Cont.

\begin{tabular}{cccc}
\hline Name & Peptide Sequence & Species & Reference \\
\hline Ae-LWamide I & pQQHGLWamide & & \\
Ae-LWamide II & pQNPGLWamide & & \\
Ae-LWamide III & pQPGLWamide & & \\
Ae-LWamide IV & pQKAGLWamide & Actinia equine & {$[35]$} \\
Ae-LWamide V & pQLGLWamide & & \\
Ae-LWamide VI & RSRIGLWamide & & \\
Ae-MWamide & pQDLDIGMWamide & & \\
MMA & pQQPGLWamide & & \\
\hline As-LWamide I & pQQAGLWamide & & \\
As-LWamide II & pQHPGLWamide & & \\
As-IWamide & pQERIGIWamide & Anemonia sulcata & \\
Ae-LWamide II & pQNPGLWamide & & \\
MMA & pQQPGLWamide & & \\
\hline
\end{tabular}

pQ; pyroglutamate. ${ }^{\text {hP; }}$ hydroxyproline.

Cnidarian GLWamide cDNAs have also been identified in several different animals. Leviev et al. [34] cloned a cDNA encoding the preprohormone from $H$. magnipapillata containing 11 (eight different) immature peptide sequences. The cDNA encodes one copy each of Hym-53; NPYPGLWamide, Hym-54; GPMTGLWamide, and Hym-249; KPIPGLWamide, two copies of Hym-248; EPLPIGLWamide, and three copies of Hym-331; GPPPGLWamide along with three other predicted GLWamides (Table 2). One of the predicted peptides, termed Hydra-LWamide VIII, is likely to include GMWamide at the $C$-terminus [34]. In Hydractinia echinata, one cDNA encoding GLWamides was cloned [35]. The cDNA encodes one copy of He-LWamide I and 17 copies of He-LWamide II (Table 2). Compared with the preprohormone of GLWamides, two distinct cDNAs were cloned from the anthozoans, Actinia equine and Anemonia sulcata [35]. The cDNA from Actinia encodes one copy each of MMA, Ae-LWamide IV, Ae-LWamide V, Ae-LWamide VI, and Ae-MWamide, two copies each of Ae-LWamide I and Ae-LWamide III, and four copies of Ae-LWamide II (Table 2). On the other hand, the cDNA from Anemonia encodes one copy each of MMA, Ae-LWamide II, and As-IWamide, two copies of As-LWamide II, and four copies of As-LWamide I (Table 2) [35]. The original MMA is only contained in anthozoan preprohormones and not in hydrozoan preprohormones. Thus, MMA is a species-specific peptide. In addition, the peptide may be a prototype of the family with protection of the $N$-terminus by pyroglutamate [36]. Two further peptides that are possibly encoded in the preprohormone of Actinia and Anemonia are likely to be processed into -GMWamide (Ae-MWamide) and -GIWamide (As-IWamide) at the $C$-termini, respectively (Table 2). These two peptides do not belong to the GLWamide family, because replacement of Leu in GLWamide with Met or Ile results in complete or almost complete disappearance of contractile activity in the parietal muscle of Anthopleura fuscoviridis [37], suggesting that other novel neuropeptide families may exist.

\subsection{Hym-355}

The primary structure of Hym-355 is FPQSFLPRGamide (Table 3) [10]. Muneoka et al. [38] proposed to group peptides with a PRXamide sequence at their $C$-termini as PRXamide peptides. 
These are further divided into three sub-groups: (a) pheromone biosynthesis activating neuropeptides [39] and related peptides; (b) small cardioactive peptides [40,41]; and (c) antho-RPamide [33] and related peptides. Thus, PRXamide peptides are widely distributed in invertebrates. Hym-355; FPQSFLPRGamide shares some homology with members of the last group: LPPGPLPRPamide (Table 3), AAPLPRLamide from the echiuran, Urechis unicinctus [42], and QPPLPRYamide and pQPPLPRYamide from the snail, Helix pomatia [43].

Table 3. PRXamide peptides in Cnidaria.

\begin{tabular}{cccc}
\hline Name & Peptide Sequence & Species & Reference \\
\hline Hym-355 & FPQSFLPRGamide & Hydra magnipapillata & {$[10]$} \\
Antho-RPamide & LPPGPLPRPamide & Anthopleura elegantissma & {$[33]$} \\
\hline
\end{tabular}

A persistent question regarding the comparative physiology of nervous systems is whether cnidarians contain the oxytocin-vasopressin superfamily of peptides, which are neurohypophysial hormones in vertebrates. In Hydra, vasopressin- and oxytocin-like immunoreactivity in the nervous system has been regarded as evidence for the presence of the oxytocin-vasopressin superfamily of peptides [44,45]. Morishita et al. [46] have purified two peptides, FPQSFLPRGamide (Hym-355) and SFLPRGamide, from $H$. magnipapillata using high performance liquid chromatography fractionation and immunological assays. They concluded that Hym-355; FPQSFLPRGamide and SFLPRGamide are the substances that account for the vasopressin-like immunoreactivity in the hydra nervous system. As Hym-355; FPGSFLPRGamide and vasopressin share the same sequence of the $C$-terminus (PRGamide) and both antibodies do not discriminate each other, Koizumi et al. [47] carried out immunohistochemical staining using anti-Hym-355 antibody and revealed that the antibody labeled the nerve rings in Cladonema radiatum and Turritopsis nutricula (order Anthomedusae, respectively). Whether Hym-355; FPQSFLPRGamide functions as a neurohypophysial hormone remains unclear.

\section{Functional Diversity of Cnidarian Neuropeptides}

\subsection{Role of FLPs in Muscle Contraction, Feeding, Sensory Activity, Reproduction, Metamorphosis, and Larval Movement}

Cnidarian FLPs mediate a variety of functions including control of muscle contractions, feeding, sensory activity, reproduction, metamorphosis, and larval movement. In the sea anemone C. parasitica, application of 0.1 to $1.0 \mu \mathrm{M}$ Antho-RFamide causes an increase in tone, contraction amplitude, and frequency of slow muscle contraction [48]. The same peptide induces tonic contractions in the rachis and peduncle of the colony, and in the individual autozooid polyps of $R$. kollikeri with a threshold of $5 \mathrm{nM}$ in summer colonies and $1 \mu \mathrm{M}$ in winter colonies [49]. In Hydra, Hydra-RFamide III has a dose-dependent effect on the pumping activity of the peduncle [50]. Because the gastrovascular cavity not only digests food, but also delivers nutrients throughout the body, the authors suggested that the contractility of the peduncle is akin to cardiac activity in higher organisms.

A peptide-gated ion channel in snails is gated by FMRFamide [51,52]. Three ion channel subunits of the degenerin (DEG)/epithelial $\mathrm{Na}^{+}$channel (ENaC) gene family have been cloned from Hydra and were named the Hydra $\mathrm{Na}^{+}$channels (HyNaC) 2-4 [53]. A new subunit, termed HyNaC5, was cloned, 
and expression of this gene co-localizes with $\mathrm{HyNaC2}$ and -3 at the base of the tentacles [54]. Co-expression of HyNaC5 with $\mathrm{HyNaC} 2$ and -3 in Xenopus oocytes greatly increases current amplitude after peptide stimulation and increases the affinity of the channel for Hydra-RFamide I and II [54]. A combination of $\mathrm{HyNaC} 2 / 3 / 5$ forms a peptide-gated ion channel of the $\mathrm{DEG} / \mathrm{ENaC}$ gene family that contributes to fast neurotransmission in cnidarians. Analysis of a chimera between $\mathrm{HyNaC}$ and $\mathrm{ENaC}$ is intriguing regarding the evolutionary aspects of the ion channel. From analyses of $\mathrm{HyNaCs}$, the authors speculated that release of Hydra-RFamide I and/or II leads to tentacle contractions, possibly when the animals are feeding [53,54]. Assmann and co-workers reported molecular cloning of seven more $\mathrm{HyNaC}$ subunits, HyNaC6 to HyNaC12, all of which are members of the DEG/ENaC gene family [55]. In Xenopus oocytes, these subunits assemble together with the four already known subunits into 13 different ion channels that are directly gated by Hydra-RFamide I and II with high affinity. Diminazene, an inhibitor of HyNaCs, delays tentacle movement in live Hydra. The authors showed that Hydra has a large variety of peptide-gated ion channels that are activated by a restricted number of FLPs [55]. Thus, Hydra may select FLPs for fast neuromuscular transmission. The possible function of Hydra-RFamide IV in Hydra remains unclear.

In addition to neurons, cnidarians have differentiated, highly specialized mechanoreceptor cells that play a pivotal role in the capture of prey and in defense [56]. These are phylum-specific stinging cells, named nematocytes. Ultrastructural studies showed the presence of two-cell and three-cell synaptic pathways in the tentacle epidermis of a sea anemone, including synaptic connections between nematocytes and surrounding neurons [57,58]. FLPs likely play a role in cnidarian sensory structures. The presence of immunoreactivity for FMRFamide and RFamide in the tentacles of animals from all four classes suggests that FLPs may be involved in the chemosensory regulation of cnidocyte discharge [59]. Also FMRFamide immunoreactivity has been seen in the epidermal sensory cells of the spot ocellus in Aurelia [60]. This neuronal control likely decreases the spontaneous firing activity of nematocytes.

FLPs are also involved in cnidarian reproduction, larval movement, and metamorphosis. Colonial octocorals such as $R$. kollikeri reproduce using the two-step process of spawning and exfoliation. During spawning, intact gamete follicles are released into the environment, and during exfoliation, the follicles rupture, freeing the gametes. Antho-RFamide, which is expressed in ciliated neurons within the follicle epithelia of $R$. kollikeri, induces the exfoliation of the follicle epithelium, releasing gametes into the surrounding medium [61]. Furthermore, the potency of the peptide is enhanced by light [61].

H. echinata is a colonial marine hydroid closely related to freshwater hydra. Fertilized eggs of this species undergo rapid cleavage divisions for about a day and develop into spindle-shaped planula larvae in about three days [62]. The planula larvae are able to migrate toward light [63], and they metamorphose into adult polyps when they receive appropriate environmental stimuli [64,65]. Hydra-RFamide I at $0.1 \mu \mathrm{M}$ inhibits the migration of planula larvae, which shows modulatory action of phototaxis by inhibitory myomodulating activity [63]. Additionally, metamorphosis is also inhibited by the peptide, leading to the suggestion that the endogenous FLPs have a function in stabilizing the larval stage [66]. Thus, FLPs may play a role in regulation of movement of the planula prior to metamorphosis, possibly linking movement to chemotactic or phototactic processes [67]. Collectively, because sensory neurons expressing FLPs are present in the planula larvae, planula migration and 
metamorphosis may be regulated by the release of endogenous neuropeptides in response to environmental cues.

\subsection{Role of GLWamides in Metamorphosis, Muscle Contraction, Planula Migration, Oocyte Maturation, and Spawning}

Species of the genus Hydractinia are colonial and usually live on snail shells inhabited by hermit crabs. In their life cycle, only a planula larval stage exists with no medusa stage. Upon setting, the planula larvae undergo metamorphosis and develop into polyps after approximately one week [68]; MMA induces this metamorphosis [9]. This finding demonstrates that cnidarian neuropeptides function as neurohormones and control developmental processes in addition to playing roles as neurotransmitters and neuromodulators. Hydra GLWamide peptides also induce the metamorphosis of $H$. serrata planula larvae into polyps [8,32]. An $N$-terminal deletion series revealed that a common GLWamide sequence is necessary for the induction of metamorphosis in Hydractinia. Induction of metamorphosis is very specific for the GLWamide terminus and amidation is essential [69]. Furthermore, displacement of Gly of GLWamide with one of the other common amino acids (with the exception of Cys) resulted in a decrease or in disappearance of potency, and displacement of Leu or Trp of GLWamide with one of the other common amino acids (except Cys) resulted in complete or almost complete disappearance of potency in the muscle contraction of $A$. fuscoviridis [37]. However, the precise mechanisms of the actions of the GLWamide peptides in the induction of metamorphosis are not yet clearly understood. Interestingly, larvae can be induced to undergo metamorphosis in response to a chemical signal secreted by environmental bacteria [9]. This chemical signal is most likely received by the sensory neurons of the planula larvae, which then release endogenous GLWamide peptides that act on the surrounding epithelial cells, resulting in a change in the phenotype. Because hydra develop directly from embryos into adult polyps and have no intermediate larvae stage, the precise function of the GLWamide peptides in early embryogenesis in Hydra is still an open question.

Sexual reproduction in reef-building corals also involves motile planula larvae, which undergo complex metamorphosis after location of an appropriate substrate, founding a juvenile coral colony. In the coral genus Acropora, Iwao and co-workers found that Hym-248; EPLPIGLWamide induces metamorphosis of Acropora planula larvae into polyps at high rates (approximately 100\%) and that Acropora planula respond to the peptide in a dose-dependent manner [70]. Interestingly, however, Hym-248; EPLPIGLWamide cannot induce metamorphosis in other coral genera [70,71]. Therefore, the specificity of ligand recognition by receptors appears to be dependent on the extent to which peptide(s) of particular structures are recognized in corals. In Hydractinia, the specificity is less stringent, and receptors can recognize any peptides belonging to the GLWamide family. Because Hym-248; EPLPIGLWamide is a surrogate ligand in Acropora, natural ligand(s) that are similar in structure to Hym-248; EPLPIGLWamide should be identified.

In Hydra, we found that all GLWamide peptides induce bud detachment from the parental polyp due to contraction of the sphincter muscle in the basal disk [8]. Tests of myoactivity typically employ epithelial Hydra, which are hydra with no nerve cells or any other cells that are derived from interstitial stem cells except for gland cells [72,73]. A similar effect was also observed in normal Hydra treated with the peptides. Unexpectedly, one of the Hydra GLWamide peptides, Hym-248; 
EPLPIGLWamide, not only induces bud detachment but also elongation of the body column [32]. Hydra muscle processes extending from the ectodermal and endodermal epithelial cells run perpendicular to each other. Hym-248; EPLPIGLWamide may have two types of receptors, one that is common to all GLWamide-family peptides and another that is specific to Hym-248; EPLPIGLWamide.

In Anthopleura, we also found that all GLWamide-family peptides induce contraction of the retractor muscle [32]. Immunohistochemical staining with an antibody specific for the GLWamide motif revealed intensely stained nerve cells in the retractor muscle of the sea anemone as well as in the nervous system of Hydra [32].

In H. echinata, migration of planula larvae is regulated by GLWamide and RFamide neuropeptides. One of the GLWamide family peptides, He-LWamide II $(0.01 \mu \mathrm{M})$, stimulates migration primarily by lengthening the active periods [63]. As mentioned above, Hydra-RFamide I inhibits the migration of the planula larvae. Thus, GLWamides and FLPs work antagonistically to regulate migration in planula larvae of H. echinata.

Oocyte maturation and subsequent spawning in hydrozoan jellyfish are generally triggered by light-dark cycles in nature. In sexually mature female medusas of the hydrozoan jellyfish Cytaeis uchidae (Figure 1), a light period of $1 \mathrm{~s}$ is sufficient to trigger oocyte maturation and spawning in intact medusas or medusas without umbrellas, but the oocytes cannot resume meiosis unless they are kept inside the ovary for at least $4 \mathrm{~min}$ following light stimulation [74]. We revealed that the Hym-53; NPYPGLWamide-dependent period required for oocyte maturation and spawning is $<2$ min and that the onset time of spawning after neuropeptide treatment is comparable to that after light stimulation [75]. These observations suggest that neuropeptide(s) work as hormones to mediate the initial step that determines if oocytes undergo irreversible induction of meiotic maturation after light reception.

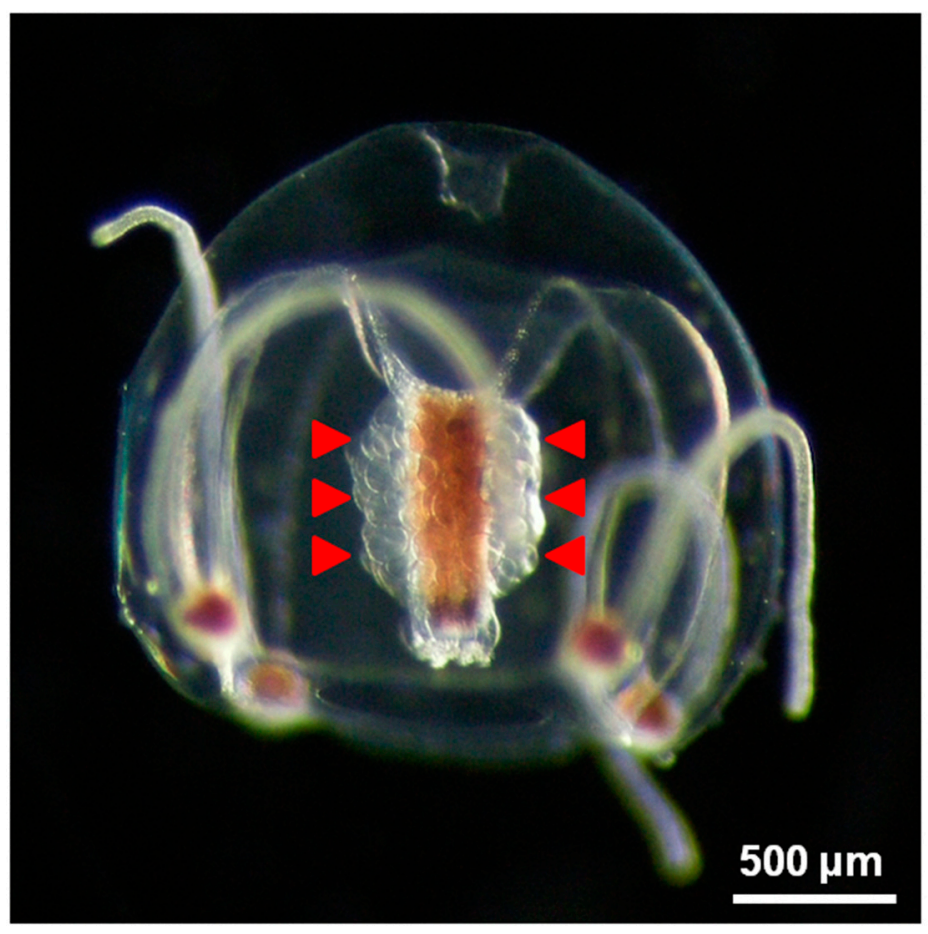

Figure 1. Morphology of an intact female Cytaeis uchidae medusa and released eggs. Fully grown oocytes in the ovary (red arrowheads) are visible around the manubrium. 


\subsection{Roles of Hym-355 in Neuron Differentiation, Muscle Contraction, Oocyte Maturation, and Spawning}

Hydra tissue is in a dynamic state and is constantly undergoing renewal due to continuous growth and differentiation of epithelial cells and interstitial stem cells. Nevertheless, neuronal density is maintained at a constant level. This neuronal homeostasis appears to be positively regulated by the neuropeptide Hym-355; FPQSFLPRGamide and negatively regulated by Pro-Trp (PW) peptide family members $[8,10,76]$. As PW peptides have a common sequence of Pro-Trp at their $C$-termini, we termed them the PW peptide family. The members are epitheliopeptides that are produced by epithelial cells [77].

Hym-355; FPQSFLPRGamide enhances neuronal differentiation at an early stage, whereas PW peptides, such as Hym-33H; AALPW, inhibit neuronal differentiation [10,76]. Furthermore, Hym-355; FPQSFLPRGamide and Hym-33H; AALPW show antagonistic properties, as treatment with one peptide nullifies the effect of treatment with the other peptide. Considering our data, these results suggest that a feedback model can explain the mechanism that regulates the homeostasis of neuronal differentiation in Hydra [10]. According to this model, Hym-355; FPQSFLPRGamide produced by neurons increases the rate of neuronal differentiation at an early stage in the pathway. On the other hand, to keep this effect in check, epithelial cells produce PW peptides that block neuronal differentiation. We propose the presence of a third factor that controls production and/or release of PW peptides from the epithelial cells and/or neurons. This tripartite mechanism presumably maintains a constant neuron density in Hydra. Hym-355; FPQSFLPRGamide is a neuropeptide that specifically enhances neuronal differentiation from interstitial stem cells in Hydra and also weakly promotes muscle contraction of the retractor muscle in the sea anemone A. fuscoviridis [10].

As mentioned above, Hym-53; NPYPGLWamide induces oocyte maturation and spawning. Hym-355; FPQSFLPRGamide also triggers these events, but the stimulatory effect is weaker than that of Hym-53; NPYPGLWamide. An antibody against Hym-355; FPQSFLPRGamide recognizes neurons located in the ovarian ectodermal epithelium [75]. Considering the effects of Hym-53; NPYPGLWamide and Hym-355; FPQSFLPRGamide on oocyte maturation and spawning in Cytaeis, we speculate that neurons that express neuropeptides may function downstream of light reception in the cnidaria. Future studies will be needed to isolate the endogenous neuropeptides that are responsible for the pathway, and will clarify the cell types that both release and respond to the molecules.

\section{Conclusions}

Peptides have long been recognized as important signaling molecules in the development and physiology of primitive metazoans such as cnidaria. In this review, we described 42 types of neuropeptides that have so far been identified in several species of cnidaria. Even in Hydra, 817 have been purified and 527 of these have been sequenced [24]. Thus, the study of neuropeptides in cnidaria is still in its infancy. We have initiated peptidomic analysis of Hydra combined with LC-MALDI-MS/MS and the Hydra expressed sequence tag database [12,77,78], the latter of which serves as a powerful tool to search for peptide receptors, which are generally GPCRs. Importantly, the approach we took here should be generally applicable to the study of signaling peptides in other organisms. 
GLWamide-related peptides are present in higher metazoans [68], and GLWamide-like immunoreactivity has been observed in the cell bodies of neurons and in thin varicose fibers in some regions of the rat brain [79]. Novel neuropeptides are likely to provide a new and effective means to explore the mechanisms that underlie physiological and developmental processes in cnidarians and most likely will increase our understanding of peptide function in higher metazoans as well.

Hydra are often used as a model system for studying developmental mechanisms such as morphogenesis, patterning, and differentiation. Recently, Glauber et al. [80] initiated a Hydra head regeneration screen of a small molecule library and identified a novel small molecule, 6-(4-dimethylaminophenyl)-4-methylpyridin-2(1H)-one, which induces extra tentacles during regeneration. This is the first report of an unbiased small molecule screen for modulators of patterning in a whole-animal system. Retinoic acid (RA) is important for developmental processes in bilateria, and the RA receptor (RAX receptor; RXR) is involved in metamorphosis. Fuchs et al. [81] revealed that RA signaling is involved in the initiation of metamorphosis in response to a temperature shift in the moon jelly Aurelia aurita, in which the life cycle alternates between sessile asexual polyps and pelagic medusas. These findings underscore the importance of scyphozoan cnidarians in evolutionary studies and indicate that RA signaling is important for the life-cycle regulation machinery throughout the animal kingdom.

\section{Acknowledgments}

The authors acknowledge a Grant-in-Aid for Scientific Research (C) to Toshio Takahashi (Grant number 26440184) and a Grant-in Aid for Young Scientists (B) to Noriyo Takeda (Grant number 26840073).

\section{Conflicts of Interest}

The authors declare no conflict of interest.

\section{References}

1. Nillni, E.A.; Luo, L.G.; Jackson, I.M.; McMillan, P. Identification of the thyrotropin-releasing hormone precursor, its processing products, and its coexpression with convertase 1 in primary cultures of hypothalamic neurons: Anatomic distribution of PC1 and PC2. Endocrinology 1996, $137,5651-5661$.

2. Truman, J.W. The eclosion hormone synthesis of insects. Prog. Brain Res. 1992, 92, 361-374.

3. Cottrell, G.A. The first peptide-gated ion channel. J. Exp. Biol. 1997, 200, 2377-2386.

4. Brogiolo, W.; Stocker, H.; Ikeya, T.; Rintelen, F.; Fernandez, R.; Hafen, E. An evolutionally conserved function of the Drosophila insulin receptor and insulin-like peptides in growth control. Curr. Biol. 2001, 11, 213-221.

5. Fujisawa, T.; Hayakawa, E. Peptide signaling in Hydra. Int. J. Dev. Biol. 2012, 56, 543-550.

6. Grimmelikhuijzen, C.J.P.; Leview, I.; Carstensen, K. Peptides in the nervous system of cnidarians: Structure, function and biosynthesis. Int. Rev. Cytol. 1996, 167, 37-89. 
7. Kass-Simon, G.; Pierobon, P. Cnidarian chemical neurotransmission, an updated overview. Comp. Biochem. Physiol. A Mol. Integr. Physiol. 2007, 146, 9-25.

8. Takahashi, T.; Muneoka, Y.; Lohmann, Y.; deHaro, M.S.L.; Solleder, G.; Bosch, T.C.G.; David, C.N.; Bode, H.R.; Koizumi, O.; Shimizu, H.; et al. Systematic isolation of peptide signal molecules regulating development in hydra: LWamide and PW families. Proc. Natl. Acad. Sci. USA 1997, 94, 1241-1246.

9. Leitz, T.; Morand, K.; Mann, M. Metamorphosin A: A novel peptide controlling development of the lower metazoan Hydractinia echinata (Coelenterata, Hydrozoa). Dev. Biol. 1994, 163, 440-446.

10. Takahashi, T.; Koizumi, O.; Ariura, Y.; Romanovitch, A.; Bosch, T.C.G.; Kobayakawa, Y.; Mohri, S.; Bode, H.R.; Yum, S.; Hatta, M.; et al. A novel neuropeptide, Hym-355, positively regulates neuron differentiation in Hydra. Development 2000, 127, 997-1005.

11. Moosler, A.; Rinehart, K.L.; Grimmelikhuijzen, C.J.P. Isolation of four novel neuropeptides, the Hydra RFamides I-IV, from Hydra magnipapillata. Biochem. Biophys. Res. Commun. 1996, 229, 596-602.

12. Takahashi, T.; Fujisawa, T. Peptidomic approaches to the identification and characterization of functional peptides in Hydra. Methods Mol. Biol. 2010, 615, 275-292.

13. Karas, M.; Bachmann, D.; Bahr, U.; Hillenkamp, F. Matrix-assisted ultraviolet laser desorption of nonvolatile compounds. Int. J. Mass Spectrom. Ion Process. 1987, 78, 53-68.

14. Karas, M.; Hillenkamp, F. Laser desorption ionization of proteins with molecular masses exceeding 10,000 daltons. Anal. Chem. 1988, 60, 2299-2301.

15. Price, D.A.; Greenberg, M.J. Structure of a molluscan cardioexcitatory neuropeptide. Science 1977, 97, 670-671.

16. Price, D.A.; Greenberg, M.J. Purification and characterization of a cardioexcitatory neuropeptide from the central ganglia of a bivalve mollusk. Prep. Biochem. 1977, 7, 261-281.

17. Price, D.A.; Greenberg, M.J. The hunting of the FaRPs: The distribution of FMRFamide-related peptides. Biol. Bull. 1989, 177, 198-205.

18. Espinoza, E.; Carrigan, M.; Thomas, S.G.; Shaw, G.; Edison, A.S. A statistical view of FMRFamide neuropeptide diversity. Mol. Neurobiol. 2000, 21, 35-56.

19. Krajniak, K.G. Invertebrate FMRFamide related peptides. Protein Pept. Lett. 2013, 20, 647-670.

20. Moosler, A.; Rhinehart, K.L.; Grimmelikhuijzen, C.J.P. Isolation of three novel peptides, the Cyanea-RFamides I-III, from scyphomedusae. Biochem. Biophys. Res. Commun. 1997, 236, 743-749.

21. Grimmelikhuijzen, C.J.P.; Hahn, M.; Rhinehart, K.L.; Spencer, A.N. Isolation of Glu-Leu-Gly-Gly-Arg-Phe-NH2. Brain Res. 1988, 475, 198-203.

22. Grimmelikhuijzen, C.J.P.; Rhinehart, K.L.; Spencer, A.N. Isolation of the neuropeptide $<$ Glu-Trp-Leu-Lys-Gly-Arg-Phe-NH2 (Pol-RFamide II) from the hydromedusa Polyorchis penicillatus. Biochem. Biophys. Res. Commun. 1992, 183, 375-382.

23. Darmer, D.; Hauser, F.; Nothacker, H.P.; Bosch, T.C.G.; Williamson, M.; Grimmilikhuijzen, C.J.P. Three different prohormones yield a variety of Hydra-RFamide (Arg-Phe- $\mathrm{NH}_{2}$ ) neuropeptides in Hydra magnipapillata. Biochem. J. 1998, 332, 403-412.

24. Fujisawa, T. Hydra peptide project 1993-2007. Dev. Growth Differ. 2008, 50, S257-S268.

25. Gajewski, M.; Schmutzler, C.; Plickert, G. Structure of neuropeptide precursors in cnidarian. Ann. N. Y. Acad. Sci. 1998, 839, 311-315. 
26. Grimmelikhuijzen, C.J.P.; Graff, D. Isolation of <Glu-Gly-Arg-Phe-NH2 (Antho-RFamide), a neuropeptide from sea anemones. Proc. Natl. Acad. Sci. USA 1986, 83, 9817-9821.

27. Anctil, M. Chemical transmission in the sea anemone Nematostella vectensis: A genomic perspective. Comp. Biochem. Physiol. D 2009, 4, 268-289.

28. Darmer, D.; Schmutzler, C.; Diekhoff, D.; Grimmelikhuijzen, C.J.P. Primary structure of the precursor for the sea anemone neuropeptide Antho-RFamide (<Glu-Gly-Arg-Phe- $\mathrm{NH}_{2}$ ). Proc. Natl. Acad. Sci. USA 1991, 88, 2555-2559.

29. Schmutzler, C.; Darmer, D.; Diekhoff, D.; Grimmelikhuijzen, C.J.P. Identification of a novel type of processing sites in the precursor for the sea anemone neuropeptide Antho-RFamide (<Glu-Gly-Arg-Phe-NH2) from Anthopleura elegantissima. J. Biol. Chem. 1992, 267, 22534-22541.

30. Reinscheid, R.K.; Grimmelikhuijzen, C.J.P. Primary structure of the precursor for the anthozoan neuropeptide Antho-RFamide from Renilla kollikeri: Evidence for unusual processing enzymes. J. Neurochem. 1994, 62, 1214-1222.

31. Schmutzler, C.; Diekhoff, D.; Grimmelikhuijzen, C.J.P. The primary structure of the Pol-RFamide neuropeptide precursor protein from the hydromedusa Polyorchis penicillatus indicates a novel processing proteinase activity. Biochem. J. 1994, 299, 431-436.

32. Takahashi, T.; Kobayakawa, Y.; Muneoka, Y.; Fujisawa, Y.; Mohri, S.; Hatta, M.; Shimizu, H.; Fujisawa, T.; Sugiyama, T.; Takahara, M.; et al. Identification of a new member of the GLWamide peptide family: Physiological activity and cellular localization in cnidarian polyps. Comp. Biochem. Physiol. Part B 2003, 135, 309-324.

33. Carstensen, K.; Rinehart, K.L.; McFarlane, I.D.; Grimmelikhuijzen, C.J.P. Isolation of Leu-Pro-Pro-Gly-Pro-Leu-Pro-Arg-Pro-NH2 (Antho-RPamide), an $\mathrm{N}$-terminally protected, biologically active neuropeptide from sea anemones. Peptides 1992, 13, 851-857.

34. Leviev, I.; Williamson, M.; Grimmelikhuijzen, C.J.P. Molecular cloning of a preprohormone from Hydra magnipapillata containing multiple copies of Hydra-LWamide (Leu-Trp- $\mathrm{NH}_{2}$ ) neuropeptides: Evidence for processing at Ser and Asn residues. J. Neurochem. 1997, 68, 1319-1325.

35. Gajewski, M.; Leitz, T.; Schlosherr, J.; Plickert, G. LWamides from cnidaria constitute a novel family of neuropeptides with morphogenetic activity. Roux's Arch. Dev. Biol. 1996, 205, 232-242.

36. Leitz, T.; Lay, M. Metamorphosin A is a neuropeptide. Roux's Arch. Dev. Biol. 1995, 204, 276-279.

37. Takahashi, T.; Ohtani, M.; Muneoka, Y.; Aimoto, S.; Hatta, M.; Shimizu, H.; Fujisawa, T.; Sugiyama, T.; Koizumi, O. Structure-activity relation of LWamide peptides synthesized with a multipeptide synthesizer. In Peptide Chemistry 1996; Kitada, C., Ed.; Protein Research Foundation: Osaka, Japan, 1997; pp. 193-196.

38. Muneoka, Y.; Takahashi, T.; Kobayashi, M.; Ikeda, T.; Minakata, H.; Nomoto, K. Phylogenetic aspects of structure and action of molluscan neuropeptides. In Perspectives in Comparative Endocrinology; Davey, K.G., Peter, R.E., Tobe, S.S., Eds.; National Research Council of Canada: Toronto, ON, Canada, 1994; pp. 109-118.

39. Raina, A.K.; Jaffe, H.; Kempe, T.G.; Keim, P.; Blacher, R.W.; Fales, H.M.; Riley, C.T.; Klum, J.A.; Ridgway, R.L.; Haves, D.K. Identification of a neuropeptide hormone that regulates sex pheromone production in female moths. Science 1989, 244, 796-798. 
40. Morris, H.R.; Panico, M.; Karplus, A.; Lloyd, P.E.; Piniker, B. Identification by FAB-MS of the structure of a new cardioactive peptide from Aplysia. Nature 1982, 300, 643-645.

41. Lloyd, P.E.; Kupfermann, I.; Weiss, K.R. Sequence of small cardioactive peptide A: A second member of a class of neuropeptides in Aplysia. Peptides 1987, 8, 179-183.

42. Ikeda, T.; Kubota, I.; Miki, W.; Nose, T.; Takao, T.; Shimonishi, Y.; Muneoka, Y. Structures and actions of 20 novel neuropeptides isolated from the ventral nerve cords of an echiuroid worm, Urechis unicinctus. In Peptide Chemistry 1992; Yanaihara, N., Ed.; ESCOM: Leiden, The Netherlands, 1993, pp. 583-585.

43. Minakata, H.; Ikeda, T.; Fujita, T.; Kiss, T.; Hiripi, L.; Muneoka, Y.; Nomoto, K. Neuropeptides isolated from Helix pomatia. Part 2. FMRFamide-related peptides, S-Iamide peptides, FR peptides and others. In Peptide Chemistry 1992; Yanaihara, N., Ed.; ESCOM: Leiden, The Netherlands, 1993; pp. 579-582.

44. Grimmelikhuijzen, C.J.P.; Dierickx, K.; Boer, G.J. Oxytocin/vasopressin-like immunoreactivity is present in the nervous system of hydra. Neuroscience 1982, 7, 3191-3199.

45. Koizumi, O.; Bode, H.R. Plasticity in the nervous system of adult hydra. III. Conversion of neurons to expression of a vasopressin-like immunoreactivity depends on axial location. J. Neurosci. 1991, 11, 2011-2020.

46. Morishita, F.; Nitagai, Y.; Furukawa, Y.; Matsushima, O.; Takahashi, T.; Hatta, M.; Fujisawa, T.; Tunamoto, S.; Koizumi, O. Identification of a vasopressin-like immunoreactive substance in hydra. Peptides 2003, 24, 17-26.

47. Koizumi, O.; Hamada, S.; Minobe, S.; Hamaguchi-Hamada, K.; Kurumata-Shigeto, M.; Nakamura, M. The nerve ring in cnidarians: Its presence and structure in hydrozoan medusa. Zoology 2014, 118, doi:10.1016/j.zool.2014.10.001.

48. McFarlane, I.D.; Graff, D.; Grimmelikhuijzen, C.J.P. Excitatory actions of Antho-RFamide, an anthozoan neuropeptide, on muscles and conducting systems in the sea anemone Calliactis parasitica. J. Exp. Biol. 1987, 133, 157-168.

49. Anctil, M.; Grimmelikhuijzen, C.J.P. Excitatory action of the native neuropeptide Antho-RFamide in muscles in the pennatulid Renilla Kollikeri. Gen. Pharmacol. 1989, 20, 381-384.

50. Shimizu, H.; Fujisawa, T. Peduncle of Hydra and the heart of higher organisms share a common ancestral origin. Genesis 2003, 36, 182-186.

51. Cottrell, G.A.; Green, K.A.; Davis, N.W. The neuropeptide Phe-Met-Arg-Phe-NH2 (FMRFamide) can activate a ligand gated ion channel in Helix neurons. Pflugers Arch. Eur. J. Physiol. 1990, $416,612-614$.

52. Lingueglia, E.; Champigny, G.; Lazdunski, M.; Barbry, P. Cloning of the amiloride-sensitive FMRFamide peptide-gated sodium channel. Nature 1995, 378, 730-733.

53. Golubovic, A.; Kuhn, A.; Williamson, M.; Kalbacher, H.; Holstein, T.W.; Grimmelikhuijzen, C.J.P.; Grunder, S. A peptide-gated ion channel from the freshwater polyp Hydra. J. Biol. Chem. 2007, 282, 35098-35103.

54. Durrnagel, S.; Kuhn, A.; Tsiairis, C.D.; Williamson, M.; Kalbacher, H.; Grimmelikhuijzen, C.J.P.; Holstein, T.W.; Grunder, S. Three homologous subunits form a high affinity peptide-gated ion channel in Hydra. J. Biol. Chem. 2010, 285, 11958-11965. 
55. Assmann, M.; Kuhn, A.; Durrnagel, S.; Holstein, T.W.; Grunder, S. The comprehensive analysis of $\mathrm{DEG} / \mathrm{ENaC}$ subunits in Hydra reveals a large variety of peptide-gated channels, potentially involved in neuromuscular transmission. BMC Biol. 2014, 12, 84.

56. Tardent, P. The cnidarian cnidocyte, a high tech cellular weaponry. BioEssays 1995, 17, 351-362.

57. Holtmann, M.; Thurm, U. Mono- and oligo-vesicular synapses and their connectivity in a Cnidarian sensory epithelium (Coryne tubulosa). J. Comp. Neurol. 2001, 432, 537-549.

58. Westfall, J.A.; Elliott, C.F.; Carlin, R.W. Ultrastructural evidence for two-cell and three-cell neural pathways in the tentacle epidermis of the sea anemone Aiptasia pallida. J. Morphol. 2002, 251, 83-92.

59. Anderson, P.A.; Thompson, L.F.; Moneypenny, C.G. Evidence for a common pattern of peptidergic innervations of cnidocytes. Biol. Bull. 2004, 207, 141-146.

60. Nakanishi, N.; Hartenstein, V.; Jacobs, D.K. Development of the rhopalial nervous system in Aurelia sp. 1 (Cnidaria, Scyphozoa). Dev. Genes Evol. 2009, 219, 301-317.

61. Tremblay, M.E.; Henry, J.; Anctil, M. Spawning and gamete follicle rupture in the cnidarian Renilla Koellikeri: Effects of putative neurohormones. Gen. Comp. Endocrinol. 2004, 137, 9-18.

62. Plickert, G.; Kroiher, M.; Munck, A. Cell proliferation and early differentiation during embryonic development and metamorphosis of Hydractinia echinata. Development 1988, 103, 795-803.

63. Katsukura, Y.; Ando, H.; David, C.N.; Grimmelikhuijzen, C.J.P.; Sugiyama, T. Control of planula migration by LWamide and RFamide neuropeptides in Hydractinia echnata. J. Exp. Biol. 2004, 207, 1803-1810.

64. Leitz, T. Metamorphosin A and related compounds: A novel family of neuropeptides with morphogenetic activity. Ann. N.Y. Acad. Sci. 1998, 839, 105-110.

65. Leitz, T. Induction of metamorphosis of the marine hydrozoan Hydractinia echnata Fleming, 1828. Biofouling 1998, 12, 173-187.

66. Katsukura, Y.; David, C.N.; Grimmelikhuijzen, C.J.P.; Sugiyama, T. Inhibition of metamorphosis by RFamide neuropeptides in planula larvae of Hydractinia echinata. Dev. Genes Evol. 2003, 213, 579-586.

67. Seipp, S.; Schmich, J.; Will, B.; Schetter, E.; Plickert, G.; Leitz, T. Neuronal cell death during metamorphosis of Hydractinia echinata (Cnidaria, Hydrozoa). Invertebr. Neurosci. 2010, 10, 77-91.

68. Takahashi, T.; Hatta, M. The importance of GLWamide neuropeptides in Cnidarian development and physiology. J. Amino Acids 2011, 2011, doi:10.4061/2011/424501.

69. Schmich, J.; Trepel, S.; Leitz, T. The role of GLWamides in metamorphosis of Hydractinia echinata. Dev. Genes Evol. 1998, 208, 267-273.

70. Iwao, K.; Fujisawa, T.; Hatta, M. A cnidarian neuropeptide of the GLWamide family indices metamorphosis of reef-building corals in the genus Acropora. Coral Reefs 2002, 21, 127-129.

71. Erwin, P.M.; Szmant, A.M. Settlement induction of Acropora palmate planulae by a GLW-amide neuropeptide. Coral Reefs 2010, 29, 929-939.

72. Marcum, B.A.; Campbell, R.D. Development of hydra lacking nerve and intestinal cells. J. Cell Sci. 1978, 29, 17-33.

73. Campbell, R.D. Elimination of Hydra intestinal and nerve cells by means of colchicines. J. Cell Sci. 1976, 21, 1-13. 
74. Takeda, N.; Kyozuka, K.; Deguchi, R. Increase in intracellular cAMP is a prerequisite signal for initiation of physiological oocyte meiosis maturation in the hydrozoan Cytaeis uchidae. Dev. Biol. 2006, 298, 248-258.

75. Takeda, N.; Nakajima, Y.; Koizumi, O.; Fujisawa, T.; Takahashi, T.; Matsumoto, M.; Deguchi, R. Neuropeptides trigger oocyte maturation and subsequent spawning in the hydrozoan jellyfish Cytaeis uhcidae. Mol. Reprod. Dev. 2013, 80, 223-232.

76. Takahashi, T.; Koizumi, O.; Hayakawa, E.; Minobe, S.; Suetsugu, R.; Kobayakawa, Y.; Bosch, T.C.G.; David, C.N.; Fujisawa, T. Further characterization of the PW peptide family that inhibits neuron differentiation in Hydra. Dev. Genes Evol. 2009, 219, 119-129.

77. Takahashi, T. Neuropeptides and epitheliopeptides: Structural and functional diversity in an ancestral metazoan Hydra. Protein Pept. Lett. 2013, 20, 671-680.

78. Fujisawa, T.; Hayakawa, E.; Takahashi, T. Systematic identification of peptide signaling molecules by combining Hydra peptide and EST projects. In Peptide Chemistry 2004; Shimohigashi, Y., Ed.; Protein Research Foundation: Osaka, Japan, 2005; pp. 21-24.

79. Hamaguchi-Hamada, K.; Fujisawa, Y.; Koizumi, O.; Muneoka, Y.; Okado, N.; Hamada, S. Immunohistochemical evidence for the existence of novel mammalian neuropeptides related to the Hydra GLW-amide neuropeptide family. Cell Tissue Res. 2009, 337, 15-25.

80. Glauber, K.M.; Dana, C.E.; Park, S.S.; Colby, D.A.; Noro, Y.; Fujisawa, T.; Chamberlin, A.R.; Steele, R.E. A small molecule screen identifies a novel compound that induces a homeotic transformation in Hydra. Development 2013, 140, 4788-4796.

81. Fuchs, B.; Wang, W.; Graspeuntner, S.; Li, Y.; Insua, S.; Herbst, E-M, Dirksen, P.; Boehm, A-M.; Hemmrich, G.; Sommer, F.; et al. Regulation of polyp-to-jellyfish transition in Aurelia aurita. Curr. Biol. 2014, 24, 263-273.

(C) 2015 by the authors; licensee MDPI, Basel, Switzerland. This article is an open access article distributed under the terms and conditions of the Creative Commons Attribution license (http://creativecommons.org/licenses/by/4.0/). 